\title{
SUBJECTIVE WELL-BEING AND FLOURISHING AT WORK: THE IMPACT OF PROFESSIONAL FULFILMENT ${ }^{1}$
}

\author{
LIGIA C. OLIVEIRA-SILVA ${ }^{2}$ \\ (iD) https://orcid.org/0000-0002-7487-9420 \\ JULIANA B. PORTO3 \\ (D) https://orcid.org/0000-0001-9164-2719
}

To cite this paper: Oliveira-Silva, L. C., \& Porto, J. B. (2021). Subjective well-being and flourishing at work: The impact of professional fulfilment. Revista de Administração Mackenzie, 22(1), 1-24. doi:10.1590/1678-6971/eRAMG210117

Submission: Jun. 12, 2019. Acceptance: Sep. 02, 2019.

\footnotetext{
Support of Institutional Program for Internationalization (PrInt) of Coordination for the Improvement of Higher Education Personnel (Capes).

2 Federal University of Uberlândia (UFU), Uberlândia, MG, Brazil.

3 University of Brasília (UnB), Brasília, DF, Brazil.
}

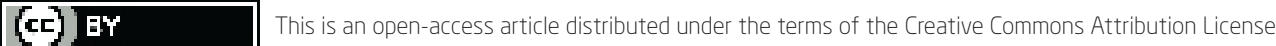

\footnotetext{
This paper may be copied, distributed, displayed, transmitted or adapted for any purpose, even commercially, if provided, in a clear and explicit way, the name of the journal, the edition, the year and the pages on which the paper was originally published, but not suggesting that RAM endorses paper reuse. This licensing term should be made explicit in cases of reuse or distribution to third parties.

Este artigo pode ser copiado, distribuído, exibido, transmitido ou adaptado para qualquer fim, mesmo que comercial, desde que citados, de forma clara e explícita, o nome da revista, a edição, o ano e as páginas nas quais o artigo foi publicado originalmente, mas sem sugerir que a RAM endosse a reutilização do artigo. Esse termo de licenciamento deve ser explicitado para os casos de reutilização ou distribuição para terceiros.
} 


\section{ABSTRACT}

Purpose: The main purpose of this study was to investigate the impact professional fulfilment has on aspects of positive psychology, such as subjective well-being and flourishing at work.

Originality/value: We analyse whether professional fulfilment, as a career aspect, influences only work factors, such as flourishing, or if it also contributes to subjective well-being in life. Additionally, few studies have focused on professional fulfilment because of its novelty. Therefore, this study contributes to advancing a new concept, as well as to the development of new models and theories in positive psychology.

Design/methodology/approach: This is a quantitative, survey-type research study involving 358 participants who have a wide variety of jobs and professions. The questionnaire presented subjective wellbeing, flourishing at work and professional fulfilment scales, as well as socio-demographic questions. Data were analysed using bivariate correlations and multiple regression analysis.

Findings: Results indicated that professional fulfilment predicts higher subjective well-being and flourishing at work. Therefore, the more people perceive they have achieved what they value in their career and demonstrate positive goal progress, the more they experience well-being in life in general and the more they flourish at work. There are major positive relationships between career goals, well-being and flourishing at work, which is consistent with previous studies. Future studies could analyse under which specific contextual conditions the pursuit of career goals has a higher or lower impact on subjective well-being and flourishing.

\section{KEYWORDS}

Subjective well-being. Flourishing at work. Professional fulfilment. Career. Goals. 


\section{INTRODUCTION}

With the development and popularity of positive psychology in recent years, subjective well-being (SWB) has received significant attention from researchers. Since the emergence of the field over five decades ago, the SWB literature has rapidly advanced. Psychologists and other social scientists have taken steps in defining and understanding SWB, which is currently conceptualised as "a person's cognitive and affective evaluations of his or her life" (Diener, Oishi, \& Lucas, 2002, p. 63). In addition to overall life evaluations, we need to consider the role that work plays in our existence to better understand the positive functioning of people. In that sense, it is essential to regard the flourishing concept, especially in the work context, as it still represents a relatively new approach in positive organisational behaviour (POB) (Luthans, 2002). Recent studies on flourishing tend to associate the concept with meaningful work, as it may be a primary avenue for the development and exercise of human capabilities and skills, aside from instilling virtues, such as honour, pride, dignity and self-respect (Veltman, 2015).

The career we develop throughout our lives is also an important aspect that affects our evaluations about life, as well as the relationship we build with our work. Consequently, when considering the career context and positive psychological states, the professional fulfilment concept should be accounted for, as it highlights the need to advance beyond the organisational setting and formal jobs when discussing career options (Hall, 2002; Briscoe \& Hall, 2006). How to achieve professional fulfilment is a frequent question people ask when they consider their career path and how to make the most of it. To perceive oneself as professionally fulfilled certainly involves effective career development and management, but achieving professional fulfilment is essentially related to fulfilling people's core needs regarding their career (Oliveira-Silva, Porto, \& Arnold, 2019).

Although SWB is a frequently investigated variable in the field of positive psychology; flourishing and professional fulfilment remain scarce in the literature. Considering the relevance of one's own career path in the promotion of well-being, the main purpose of this paper is to investigate the impact professional fulfilment has on positive psychological aspects, such as SWB and flourishing at work. Subsequently, it would be possible to analyse whether the impact of professional fulfilment is solely on work related factors or if it is on life as a whole.

Given the lack of studies regarding the professional fulfilment concept, this investigation is relevant, as it analyses the consequences for vital positive 
psychology aspects such as SWB and flourishing; also, it indicates the results of fostering professional fulfilment in one's career. Thus, it contributes to the advancement of a new concept, as well as to the development of new models and theories in positive psychology. Additionally, it analyses the antecedence-consequence interactions among distinct domains such as life, career and work, which is still rare in the POB literature.

\section{PROFESSIONAL FULFILMENT, SUBJECTIVE WELL-BEING, AND FLOURISHING AT WORK}

Professional fulfilment is related to how people pursue their career goals and how they evaluate their goal progress, which engenders a two-dimension comprehension of the concept (Oliveira-Silva et al., 2019). To analyse people's professional fulfilment, we needed to observe the importance and achievement of specific types of goals and people's evaluation of goal progress. This means that the concept of professional fulfilment involves two dimensions: 1 . content of goals, which indicates what types of goals matter most to the individual; and 2. evaluation of goals or goal progress, which refers to how satisfied one feels with the degree of attainment of career goals (Oliveira-Silva et al., 2019). The content dimension of professional fulfilment engenders the human value structure as proposed by Schwartz (1992) and Schwartz et al. (2012), according to which values are defined as criteria or goals that transcend specific situations, are ordered by their importance and serve as principles that guide an individual's life.

In summary, professional fulfilment concerns people's beliefs about their career goals, being defined as the perception of having attained one's most important career goals or the positive evaluation of being on the right track for attaining career goals (Oliveira-Silva et al., 2019). It considers individual criterion concerning the attainment of goals, represents a cognitive concept and takes into account work and personal values to understand and categorise career goals (Oliveira-Silva, 2015). People could experience professional fulfilment not only by fully achieving their goals, but also by evaluating whether they are on the right track to achieve it or perceive that they have somehow contributed to their goal's cause. Therefore, professional fulfilment is not only about the ends - it is also about the means (Oliveira-Silva, 2015).

As professional fulfilment represents a career aspect related to individual self-fulfilment and positive functioning, positive human aspects such as SWB should be considered in this regard. In short, SWB comprises three 
elements: 1. life satisfaction; 2 . positive affect; and 3. negative affect (Anguas, 1997; Martinez \& Garcia, 1994). Life satisfaction is considered to be the cognitive element of SWB and refers to what one thinks about his or her life satisfaction as a whole and in terms of domain (areas of life such as work and relationships) (Emmons, 1986). Regarding affect, SWB experience occurs when the presence of positive affect is higher than negative affect. Affect is positive when the experienced emotions, moods and feelings are pleasant (e.g. joy, elation, affection), but is negative when they are unpleasant (e.g. guilt, anger, shame) (Diener, 1995). A person with a high level of satisfaction with life, greater positive affect and little or less negative affect would have a high level of SWB, which is considered an equivalent of happiness (Diener, 2001).

Publications regarding the relationship between the achievement of one's most important goals, goal progress and SWB, for example, date back to the 1980s. Emmons (1986) and Cantor and Sanderson (1999), for example, clearly identified that making progress toward goals is related to SWB. According to Carver (2004), pleasant feelings related to the affective component of SWB arise when the progress rate towards a goal is faster than anticipated. On the other hand, unpleasant feelings arise when the progress rate towards a goal is slower than anticipated. Several well-being theories have posited that it is the active pursuit of goals, rather than their complete fulfilment, that contributes to well-being (Cantor \& Sanderson, 1999), which is in line with the premise of professional fulfilment, in which perceiving to be on the right track to achieve one's most important goals is also crucial.

Additionally, Brunstein, Schultheiss, and Grässmann (1998) reveal that only an advancement toward personally meaningful goals predicts increases in well-being. In a similar vein, Oishi, Diener, Suh, and Lucas (1999) found that people feel better when they make progress toward highly valued goals than they do when they achieve less valued goals. Diener and Fujita (1995) evidenced that having resources (e.g., money, physical attractiveness or social skills) in areas related to one's most important goals is a more accurate predictor of happiness than having resources that are unrelated to one's important goals. Building on self-determination theory, Sheldon and Elliot (1999) demonstrated that, when individuals' goals are congruent with their personal values, they are more likely to experience general well-being. In other words, goal fulfilment is associated with greater well-being, but only if goals are consistent with an individual's core values (Sheldon \& Elliot, 1999). Finally, Klug and Maier (2015) provided a quantitative review of the link between successful goal pursuit and SWB. Their meta-analysis integrated 
findings from 108 independent samples derived from 85 studies, showing robust evidence that goal pursuit is related to SWB.

This body of evidence is in line with the premise that professional fulfilment, as a career goal concept, influences well-being. However, it is needed to analyse how career goals, in terms of content and progress, influence SWB when individually considering the three components of well-being. This is in accordance with premises that these components are independent factors and therefore should be measured and studied separately (Andrews \& Withey, 1976; Lucas, Diener, \& Suh, 1996). Thus, the following hypotheses are proposed:

- H1a: The professional fulfilment goal content dimension is a stronger predictor of positive affect than of negative affect.

- H1b: The professional fulfilment goal progress dimension is a stronger predictor of positive affect than of negative affect.

- H2a: The professional fulfilment goal content dimension positively predicts life satisfaction.

- H2b: The professional fulfilment goal progress dimension positively predicts life satisfaction.

Similarly to SWB, some authors state that flourishing at work includes both a hedonic aspect, wherein it involves positive emotions and satisfaction at work, and a eudemonic aspect, which involves being fully engaged in work and it is an expression of the true self (Peterson, Park, \& Seligman, 2006). According to Mehrotra and Tripathi (2013), from a general perspective, flourishing is a state of positive mental health that comprehensively captures the aspects of "feeling good", as well as positive psychosocial functioning. It is achieved when an individual experiences a high level of purpose, meaning, optimism, competence and satisfaction with life (Diener et al., 2010). According to the POB perspective, flourishing at work refers to a prosperity and development situation, linked to a progressive state of satisfaction and well-being at the work context (Mendonça, Caetano, Ferreira, Sousa, \& Silva, 2014).

The premise that professional fulfilment may engender flourishing at work is based on evidence that some employees are more likely to flourish than others. Even when they share the same working conditions, aspects such as personality traits, values and goals lead them to engage in certain behaviours, to pursue specific goals or strategies and to interpret and find meaning in their experiences in systematic ways (McAdams, 1995; Bono, Davies, \& Rasch, 2011). The proposition is that people who fulfil them- 
selves through the achievement of fundamental goals and present a positive goal progress evaluation may present distinct levels of flourishing at work. When people experience professional fulfilment, it is more likely that they are involved in meaningful work, which also represents an indicator of flourishing at work (Veltman, 2015). According to these rationales, the following hypotheses are proposed:

- H3a: The professional fulfilment goal content dimension positively predicts flourishing at work.

- H3b: The professional fulfilment goal progress dimension positively predicts flourishing at work.

Combined, therefore, all hypotheses explicitly state the main purpose of this study, which is to investigate the impact of professional fulfilment on positive psychology aspects such as SWB and flourishing at work. Next, the method used to test such hypotheses is presented, as well as the resultant model and implications for research.

\section{METHOD}

\subsection{Participants}

Considering that SWB and flourishing at work present considerable similarities in terms of their definition and measurements, data from two different and independent samples was used. This strategy contributes to avoid the overlapping of well-being and flourishing among respondents, considering that participants can mistake them as being quite similar and, consequently, respond to them in an analogous manner (Gevers, Mohammed, \& Baytalskaya, 2015). Besides, the use of two samples should contribute to avoid multicollinearity, which is a vital assumption of multiple regression (Tabachnick \& Fidell, 2001).

- Sample 1: Participants included 179 workers between 18 and 54 years of age (mean $=27$ years), most of whom were women $(74 \%)$, single $(65 \%)$ and had attained an undergraduate $(95.5 \%)$ college degree (including second or third graduations). Overall, their average work tenure was 6.5 years, while work tenure in the same organisation was 3.7 years. Most of them $(80.7 \%)$ did not occupy a leadership position. Participants assumed a large variety of jobs and professions, which included positions in 
organisations and autonomous jobs. This sample responded to professional fulfilment and SWB instruments.

- Sample 2: Participants included 358 workers, most of whom were women $(67 \%)$ and single (57\%). Schooling ranged up to postgraduate level, but most participants were college undergraduates $(87.3 \%)$. The mean age was 29 years old, with the youngest being 17 and the oldest 64 . The mean for work tenure was 8.3 years, with the minimum being less than a year working and the maximum 43 years. This sample responded to professional fulfilment and flourishing at work instruments.

\subsection{Instruments}

The Professional Fulfilment Scale - PFS (Oliveira-Silva et al., 2019) was used to measure professional fulfilment. The scale is comprised of two dimensions. The first, goal content, explores what types of career goals people perceive as being more important and how much they achieve at present. To observe the relationship between importance and achievement, the professional fulfilment degree indicator (PFDI) score is calculated, obtained through the formula: PFDI $=\mathrm{i}(\mathrm{a}-1)$, in which $\mathrm{i}=$ importance and $\mathrm{a}=$ achievement. The minimum PFDI score is 0 (obtained with any value of importance and zero achievement), while the maximum score is 12 (maximum importance and achievement). Such a score shows that an unimportant goal that is less achieved is less unfavourable than when an important goal has no achievement at all. This dimension presents 16 items and four factors - self-transcendence, self-enhancement, conservation, and openness to change. To obtain PFDI, a mean of these four factors is calculated.

The second dimension, goal progress, analyses people's progress towards their career goals and their satisfaction with that. It presents one open question, a dichotomous question concerning whether the person has achieved the stated career goal and four scale questions: 1. how far is the person from achieving the goal; 2 . how much does their current job contribute to achieving the goal; 3 . how satisfied are they with the degree of goal progress; 4 . how professionally fulfilled do they perceive themselves to be (Oliveira-Silva et al., 2019).

Results from confirmatory analysis indicate that PFS presents very good fit properties: $\chi^{2}=148.83, \chi^{2} / \mathrm{df}=1.55, \mathrm{p}=0.000, \mathrm{CFI}=0.98$, TLI $=0.97$, RMSEA $=0.04$, SRMR $=0.03$ (Oliveira-Silva et al., 2019). Cronbach's alpha for the complete scale is equal to 0.92, whilst alphas for the four factors from the first dimension, including importance and achievement scales separately, 
range from 0.72 to 0.91 . For the goal content dimension, alpha was equal to 0.78 (Oliveira-Silva et al., 2019). Considering the samples used, the reliability index for PFDI was equal to 0.92 and 0.78 for the goal progress dimension.

To measure SWB, Escala de Bem-estar Subjetivo (EBES) was used (Albuquerque \& Trócolli, 2004). It presents 62 items, which comprehend three dimensions of SWB: satisfaction with life, positive affect, and negative affect. Answers vary from 1 (not at all) to 5 (extremely). The complete scale presents 0.86 for reliability. In the sample used, the complete scale presented 0.77 for reliability, 0.77 for the satisfaction with life factor, 0.93 for the positive affect factor and 0.94 for negative affect.

Flourishing at work was measured through Escala de Florescimento no Trabalho - EFLOT (Mendonça et al., 2014), which represents an adaptation from Diener et al. (2010) and Silva and Caetano (2011) to work context and to Brazilian Portuguese, respectively. It presents eight items in a seven-point scale, ranging from 1 (completely disagree) to 7 (completely agree). It is single factored, with Cronbach's $\alpha$ equal to 0.85 and items loading ranging from 0.40 to 0.75 . For the present sample, Cronbach's $\alpha$ was equal to 0.80 .

\subsection{Procedures}

Participants were recruited in their faculty classrooms, being invited to take part in career research. All participants were informed of the academic purposes of the research and its ethical procedures, besides being given the terms of informed consent (TCLE) to read and sign, if they agreed to participate in the research. Those who accepted the invitation stood in their classrooms after the lecture, which was when they were given the questionnaire.

\subsection{Data analysis}

To obtain the power achieved by the statistical tests accomplished in this study, G-Power 3 (Faul, Erdfelder, Lang, \& Buchner, 2007) was used. Estimates were obtained considering the power analysis section protocol, the T-test family and the linear multiple regression statistical test; the power analysis type was post-hoc. For an effect of 0.25 , an alpha of 0.001 , a sample size of 179 (sample 1) and two predictors (professional fulfilment dimensions), a power of 0.99 was achieved. When considering sample 2, for an effect of 0.10 , alpha of 0.001 , a sample size of 358 and two predictors; a power of 0.99 was also achieved.

Multiple regression analyses were executed in Statistical Package for Social Science (SPSS), version 20.0, in order to test the proposed hypothesis. 
Correlations and central tendency analyses were also performed in order to understand the data patterns. Regarding the goal content dimension of PFS, PFDI score was calculated, generating an overall score. Items from the goal progress dimension were also analysed together.

\section{RESULTS}

After verifying the attendance of statistical assumptions, the results from descriptive statistics and bivariate correlations were analysed, which are displayed in Figure 4.1. Regarding SWB factors, negative affect presented the smallest mean below the midpoint (3) of the scale $(\mathrm{M}=2.30)$, while positive affect $(M=3.30)$ and satisfaction with life $(M=3.39)$ presented almost identical means, both of which were above the scale midpoint. The flourishing single factor, in turn, also presented a mean $(M=5.20)$ above the midpoint (4). Regarding professional fulfilment, the PFDI mean ( $\mathrm{M}=$ 5.82) was below the midpoint (6), indicating a relatively low degree of achieving what is valued in terms of career goals. The goal progress dimension mean $(\mathrm{M}=2.64)$ was also below the midpoint $(3)$, indicating a relatively low degree of satisfaction with progress towards career goals.

\section{(Figure 4.1)}

MEANS AND CORRELATIONS AMONG SWB, FLOURISHING, AND PFS

\begin{tabular}{lccccccccc}
\hline Variables & M & Scale & SD & 1 & 2 & 3 & 4 & 5 & 6 \\
\hline 1. PA & 3.30 & $1-5$ & 0.71 & - & & & & & \\
\hline 2. NA & 2.30 & $1-5$ & 0.76 & $-0.47^{\star \star}$ & - & & & & \\
\hline 3. SL & 3.39 & 1.5 & 0.66 & $0.49^{\star \star}$ & $-0.52^{\star \star}$ & - & & \\
\hline 4. PFDI & 5.82 & $0-12$ & 2.14 & $0.42^{\star \star}$ & -0.10 & 0.12 & - & \\
\hline 5. GP & 2.64 & 1.5 & 0.60 & $0.36^{\star \star}$ & $-0.15^{\star}$ & $0.26^{\star \star}$ & $0.38^{\star \star}$ & - & \\
\hline 6. FLO & 5.20 & 1.7 & 0.99 & - & - & - & $0.39^{\star \star}$ & $0.44^{\star \star}$ & - \\
\hline
\end{tabular}

$\mathrm{PA}=$ positive affect; $\mathrm{NA}$ = negative affect; $\mathrm{SL}$ = satisfaction with life; $\mathrm{PFDI}$ = professional fulfilment degree indicator; $\mathrm{GP}=$ goal progress; FLO = flourishing at work. No correlations between flourishing and SWB dimensions were calculated because they were measured in different samples. Means calculation for PFS considered both samples. ${ }^{*} p<0.05,{ }^{* \star} p<0.01$. 
Regarding the correlation results, flourishing, positive affect and professional fulfilment were significantly correlated. However, besides being positively and significantly correlated with positive affect, only goal progress was positively and significantly correlated with satisfaction with life and negatively correlated with negative affect. PFDI, in turn, was significantly and positively correlated only with positive affect, but not with negative affect or satisfaction with life. On the other hand, both dimensions of professional fulfilment were significantly correlated with flourishing at work.

Hypotheses $\mathrm{H} 1 \mathrm{a}$ and $\mathrm{H} 1 \mathrm{~b}$ propose that professional fulfilment predicts SWB regarding positive affect, negative affect and life satisfaction. H1a posits that the professional fulfilment goal content dimension or PFDI predicts positive affect $\left(\beta=0.417, \mathrm{R}^{2}=0.174, \mathrm{p}<0.001\right)$ more than negative affect ( $\left.\beta=-0.098, \mathrm{R}^{2}=0.010, \mathrm{NS}\right)$. On the other hand, H1b proposes the same thing, but analysing the professional fulfilment goal progress dimension. According to Figure 4.2, both $\mathrm{H} 1 \mathrm{a}$ and $\mathrm{H} 1 \mathrm{~b}$ were supported. PFDI was a strong predictor of positive affect, but did not predict negative affect significantly or positively. Regarding H1b, the PFS goal progress also revealed to be a strong predictor of positive affect $\left(\beta=0.363, \mathrm{R}^{2}=0.131, \mathrm{p}<0.001\right)$ than of negative affect $\left(\beta=-0.155, R^{2}=0.024, p<0.05\right)$, although goal progress did predict negative affect significantly, albeit negatively. Comparing results from the goal content and goal progress dimensions, it is possible to observe that goal content proved to be a slightly stronger predictor of positive affect.

\section{(Figure 4.2)}

REGRESSION COEFFICIENTS FOR HYPOTHESES

\begin{tabular}{ccccccccc} 
& \multicolumn{2}{c}{ PA } & \multicolumn{2}{c}{ NA } & \multicolumn{2}{c}{$S L$} & \multicolumn{2}{c}{$F L O$} \\
\hline Predictor & $\boldsymbol{\beta}$ & $\mathrm{R}^{2}$ & $\boldsymbol{\beta}$ & $\mathrm{R}^{2}$ & $\boldsymbol{\beta}$ & $\mathrm{R}^{2}$ & $\boldsymbol{\beta}$ & $\mathrm{R}^{2}$ \\
\hline PFDI & $0.417^{\star \star}$ & 0.174 & -0.098 & 0.010 & 0.121 & 0.015 & $0.391^{\star \star}$ & 0.153 \\
\hline GP & $0.363^{\star \star}$ & 0.131 & $-0.155^{\star}$ & 0.024 & $0.265^{\star \star}$ & 0.070 & $0.437^{\star \star}$ & 0.191 \\
\hline
\end{tabular}

$P A=$ positive affect; $N A$ = negative affect; $S L$ = satisfaction with life; $P F D I$ = professional fulfilment degree indicator; $\mathrm{GP}=$ goal progress; $\mathrm{FLO}=$ flourishing at work.

${ }^{\star} p<0.05,{ }^{* \star} p<0.001$.

Source: Elaborated by the authors.

In relation to $\mathrm{H} 2 \mathrm{a}$ and $\mathrm{H} 2 \mathrm{~b}$, they address satisfaction with life and posit that both goal content and goal progress predict life satisfaction. Hypothesis 
$\mathrm{H} 2 \mathrm{a}$ proposes that goal content score - PFDI - predicts life satisfaction; the same is hypothesised for goal progress (H2b). Figure 4.2 evidences that, while $\mathrm{H} 2 \mathrm{~b}$ was supported, $\mathrm{H} 2 \mathrm{a}$ was not, as PFDI did not significantly predict life satisfaction $\left(\beta=0.121, \mathrm{R}^{2}=0.015\right.$, NS). Consequently, only goal progress was demonstrated to be a predictor of satisfaction with life $(\beta=0.265$, $\mathrm{R}^{2}=0.070, \mathrm{p}<0.001$ ).

Hypotheses $\mathrm{H} 3 \mathrm{a}$ and $\mathrm{H} 3 \mathrm{~b}$, for instance, proposed that professional fulfilment predicts flourishing at work. Whilst H3a states that PFDI predicts flourishing at work, $\mathrm{H} 3 \mathrm{~b}$ posits that flourishing is also predicted by the goal progress dimension. Figure 4.2 illustrates the regression coefficients obtained for these hypotheses, which evidences that both were supported. PFDI significantly predicted flourishing at work $\left(\beta=0.391, \mathrm{R}^{2}=0.153, \mathrm{p}<\right.$ 0.001 ), as goal progress presented the highest influence on flourishing at work $\left(\beta=0.437, \mathrm{R}^{2}=0.191, \mathrm{p}<0.001\right)$, thus, overcoming goal content.

Overall, these results indicated that professional fulfilment predicts both flourishing at work and SWB. Some aspects of professional fulfilment are better predictors than others, such as goal progress, which predicted all well-being factors. However, the goal content dimension of professional fulfilment (PFDI) failed to predict negative affect and satisfaction with life. The implications of these results are discussed further on. Considering the obtained results, Figure 4.3 displays the resultant model regarding the proposed hypotheses.

\section{(Figure 4.3)}

RESULTANT MODEL

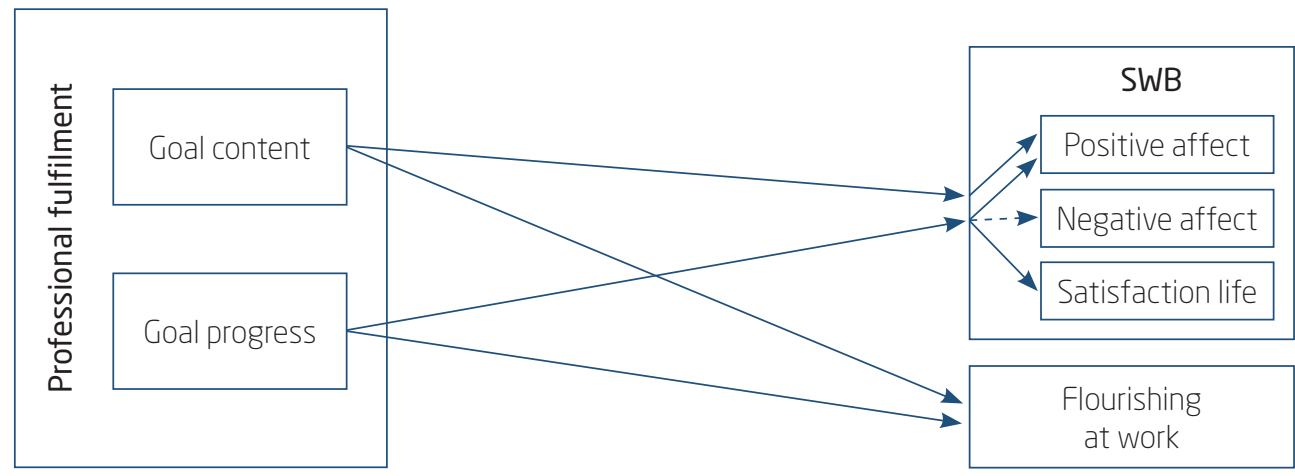

Source: Elaborated by the authors. 


\section{DISCUSSION}

The present study aimed to analyse whether SWB (which addresses life overall) and flourishing at work (which is related to positive work experiences) are fostered by professional fulfilment. Our results indicated that professional fulfilment predicts higher SWB and flourishing at work. The evidence reveals that the more people perceive that they achieve what they value in their career and demonstrate a positive goal progress evaluation, the more they experience well-being and flourish at work. This is crucial because it means that professional fulfilment is not an end in itself, but contributes to generating positive experiences not only at work, but also in life as a whole.

Regarding the relationship between professional fulfilment and SWB specifically, we verified that, when people present positive affect in life, this is fostered by achieving what they value in their career rather than when they have a positive evaluation of their goal progress. One possible explanation of this is that the goal content dimension involves more concrete goal achievement than the goal progress dimension, perhaps because the latter depends more on an optimistic attitude. Considering goal contents separately, self-enhancement and openness to change career goals yielded the strongest impact on positive affect.

However, the results also indicated that the goal content dimension (PFDI) did not significantly predict life satisfaction. The simple fact of achieving what is important in one's career does not guarantee that people will be more satisfied with life. On the other hand, presenting a positive goal progress evaluation may contribute to a better view of life, as the goal progress dimension presented a significative relationship with life satisfaction. This is quite interesting, as it indicates that a better subjective perception of how well one perceives their career performance fosters a better evaluation of life satisfaction. The sense-making for this result may be the premise that both, goal progress and life satisfaction, represent subjective evaluations influenced by one's cognitions of optimism and positivity about themselves.

Therefore, it is possible to state that professional fulfilment is a tenacious well-being predictor, while PFDI is a strong predictor of positive affect, and the goal progress dimension is identified as being a better predictor of life satisfaction. The premise that the pursuit of goals is associated with a higher SWB is not a novelty. It has been previously assumed that personal goals are precursors of life satisfaction and long-term positive and negative affect (Diener, Suh, Lucas, \& Smith, 1999; Emmons \& Kaiser, 1996). In fact, 
considerable empirical evidence has shown that people involved in the pursuit of personal goals indicate a higher SWB than individuals who lack a sense of goal directedness (Emmons, 1986; Cantor \& Sanderson, 1999). Specifically, people who pursue individually important goals experience higher levels of SWB than those who have no concrete goal in mind (Freund $\&$ Baltes, 2002). Furthermore, it is not only the pursuit of important goals that influences SWB, but also the perception of making progress or even attaining these goals (Brunstein, 1993; Wiese, 2007; Klug \& Maier, 2015).

There is, however, considerable individual variance in the link between goal progress and well-being (Kruglanski, 1996). In life-span psychology, it has been emphasised that it is adaptive to choose goals that converge with individual capacities and personal motives (Baltes \& Baltes, 1990; Heckhausen, 1999). The underlying core idea is that personal goals are hierarchically dependent on higher-order motives or needs (Emmons, 1989), which is also the idea brought about by professional fulfilment, as career goals are based on personal values. According to Klug and Maier (2015), selecting and pursuing specific goals is instrumental in fulfilling these enduring motives or needs and therefore leads to long lasting increases in SWB. Furthermore, the reason why goal pursuit predicts SWB is that, while striving for personal goals, people focus their energy on relevant activities and invest continual effort in goal pursuit. If goals are well organised in a hierarchy, these effects are even more pronounced, as goal hierarchies provide individuals with diverse and expanding opportunities to achieve their desired goal (Klug \& Maier, 2015).

The link found between a career aspect (professional fulfilment) and a general life aspect (SWB) is relevant, as the influence of development evaluation of one domain (e.g. career) within another domain (e.g. life overall) has been scarcely demonstrated. A similar example is from Wiese and Freund (2005), which proposes that the work domain goal progress is judged with reference to intra-domain standards, as well as with reference to personal development and circumstances in other life domains. Both professional fulfilment dimensions can be identified in Wiese and Freund's (2005) study, as the authors test and confirm not only the effect of positive goal progress on well-being, but also the discrepancies between one's expectations concerning goals and the actual reality of the desired state, which is their current degree of achievement.

The impact that the achievement of important career goals has on positive affect has also been previously addressed, as several studies suggest that the achievement of highly self-valued goals results in positive emotional 
states such as joy, happiness and satisfaction, besides significantly impacting SWB (Brunstein, 1993; Emmons, 1986; Hortop, Wrosch, \& Gagné, 2013; Klug \& Maier, 2015; Oishi \& Diener, 2001). The degree to which goals are self-relevant is thought to influence the size of the relationship between goal pursuit and SWB (Cantor \& Fleeson, 1994). This may also contribute to our understanding of why, in our study, PFDI is so strongly related to positive affect.

The lack of impact of both PFS dimensions on negative affect has also been previously indicated. There is evidence that successful goal pursuit is related to SWB positive indicators, especially positive affect (Emmons \& Diener, 1986; Kehr, 2003; Wanberg, Zhu, \& Van Hooft, 2010). Studies that differentiated between qualitative facets of emotional SWB and assessed positive and negative affect simultaneously largely showed that successful goal pursuit has comparatively lower-to-no effect on negative affect (Sheldon $\&$ Kasser, 1998; Wiese \& Freund, 2005). Perhaps, that is the reason why the professional fulfilment goal content failed to present even a significative influence on negative affect, except for the goal progress dimension, which presents a significative but low and inverse influence on negative affect.

Regarding the exclusive influence of goal progress on life satisfaction, the study from Monzani et al. (2015) can contribute to explaining this result, as it evidences the role of optimism on perceived goal progress. Similarly, life satisfaction has also been predicted by optimism (Scheier \& Carver, 1992; Leung, Moneta, \& McBride-Chang, 2005), which may help to explain the higher influence of goal progress on life satisfaction. A study by Jackson, Weiss, Lundquist, and Soderlind (2002) also demonstrated that optimists report more progress, higher goal value and lower levels of perceived goal conflict than pessimists. Additionally, considering that the evaluation of goal progress may be understood as a self-evaluation, there is also evidence that self-evaluations predict life satisfaction (Judge, Locke, Durham, \& Kluger, 1998).

One possible reason why PFDI did not predict life satisfaction is given by Deci and Ryan (2000) and Csikszentmihalyi (1993), according to whom personally relevant or important goals are intrinsically rewarding, express enduring interests and values and therefore serve basic needs, but do not necessarily engender satisfaction. Another reason is given by Klug and Maier (2015), who posit that, if personal goals refer to a specific domain (in this case, career) and SWB is measured with respect to a different domain (life in general), there might be a mismatch. Although they assume that spillover effects from the personal life domain to the work domain are possible, they 
argue that the relationship between successful goal achievement in one domain and SWB in a different domain may be weaker than when comparing matched cases.

Finally, the meta-analytic review from Klug and Maier (2015) reveals that an analysis of the relationship between goal pursuit and SWB is the path to be followed. They evidenced that the association of goal pursuit with positive indicators of SWB is true, that successful goal pursuit was related to goal progress and that SWB matched goal content. All of these findings are congruent with our results and enhance the relevance of professional fulfilment for SWB.

Concerning the influence of professional fulfilment on flourishing at work, goal content significantly predicted flourishing at work. This means that, when people achieve what they value in their career, it is likely that they will flourish at work. The goal progress dimension, in turn, presented the highest influence on flourishing at work, overcoming goal content. This indicates, that when people present a positive evaluation of goal progress, it is more likely that they will flourish at work. People who worry about how well they are doing in their career, in general, search for more meaningful work, where they can feel they are able to flourish. Namely, if people show good progress evaluation towards their career goals, it is more likely that they will experience competence, engagement, meaning and purpose, optimism, self-acceptance and supportive relationships at work (Diener et al., 2010; Silva \& Caetano, 2011).

Similar findings are much less common in the literature, especially in comparison with SWB, likely because flourishing is not as well developed and investigated as SWB. Flourishing represents a relatively recent concept; therefore, its investigations are usually fairly scarce and under development. A study by North, Holahan, Carlson, and Pahl (2014) evidenced that reengagement with new and intrinsically meaningful goals after failure was associated with greater subsequent flourishing. This is compatible with our findings, which demonstrate that both professional fulfilment dimensions predict higher levels of flourishing at work. The importance of such findings also relies on the connection of flourishing with positive physical health outcomes, productivity at work and absenteeism (Keyes \& Haidt, 2003).

Finally, a study from Bono et al. (2011) shows that people who flourish at work because of their personality tend to have a positive approach to the self, others and work situations. They also tend to take an active, engaged and forward-looking approach to work, especially in novel or challenging situations. These aspects may be engendered by the professional fulfilment 
experience, thus, leading people to present higher flourishing at work. Another possibility is that professional fulfilment relates to meaningful work, which also contributes to human flourishing (Veltman, 2015).

\section{FINAL CONSIDERATIONS}

In general, the present study adds to the comprehension of how professional fulfilment influences, not only work-related variables, but also general happiness in life. Despite the lack of studies reinforcing the obtained results regarding professional fulfilment, it is critical to highlight the contribution of this study to the field. A relevant contribution concerns specific career goal investigations. Most evidence reported here involves goals in general. The demonstration that career goals reproduce the results found for goals in general adds to the research, not only for distinct goal domains, but especially in the career-related field.

A relevant practical implication of this study is the comprehension that the different domains of people's lives affect each other. Therefore, to foster professional fulfilment affects, not only work-related issues, but also perceptions of life in general, recognising the wholeness of individuals. Finally, the consideration of these findings may contribute to the promotion of investing in career planning both inside and outside organisations.

Concerning the limitations of this study, one of which is its relatively simple design, analysing only direct relationships and not considering possible moderators or mediators for the relationship between professional fulfilment and SWB and flourishing at work. One of the reasons is the need to check the true and simple influence of professional fulfilment in positive psychology outcomes, stating that professional fulfilment is not an end itself. However, the role of intervenient variables is not discarded and should be considered in future studies.

Another limitation is its cross-sectional design. A longitudinal investigation on how alterations in people's career goals - level of importance, achievement or the evaluation of goal progress - alter levels of SWB and flourishing at work over time would undoubtedly be striking. The use of other strategies to measure SWB and flourishing at work rather than selfreport could also contribute to the further comprehension of the impact of professional fulfilment on these variables.

Finally, a possibility regarding further studies relies on the analysis of under which specific context the pursuit of career goals has a higher or 
lower impact on SWB and flourishing. Carver and Scheier (1998), for example, suppose that, once a goal is achieved, it loses its power to enhance SWB and can even produce negative emotions. To analyse whether the attained goal is a dead end and buffers SWB or if new goals and progress on them can maintain SWB is, at least, inquisitive.

\section{BEM-ESTAR SUBJETIVO E FLORESCIMENTO NO TRABALHO: $O$ IMPACTO DA REALIZAÇÃO PROFISSIONAL}

\section{$\int$ RESUMO}

Objetivo: O objetivo principal deste estudo foi investigar o impacto que a realização profissional tem sobre aspectos psicológicos positivos, como bem-estar subjetivo e florescimento no trabalho.

Originalidade/valor: Foi analisado se a realização profissional, como aspecto de carreira, influencia apenas fatores de trabalho, como o florescimento, ou se também contribui para o bem-estar subjetivo na vida. Além disso, existem poucos estudos com o conceito de realização profissional por conta de sua recenticidade. Portanto, este estudo contribui para o avanço de um novo conceito, bem como para o desenvolvimento de novos modelos e teorias em psicologia positiva.

Design/metodologia/abordagem: Trata-se de uma pesquisa quantitativa, do tipo survey, envolvendo 358 trabalhadores. Os participantes apresentavam variados empregos e profissões. O questionário continha as escalas de bem-estar subjetivo, florescimento no trabalho e de realização profissional, bem como questões sociodemográficas. Os dados foram analisados por meio de correlações bivariadas e análise de regressão múltipla.

Resultados: Os resultados indicaram que a realização profissional prevê maior bem-estar subjetivo e florescimento no trabalho. Logo, quanto mais as pessoas percebem que alcançam o que valorizam na carreira e demonstram uma avaliação positiva do progresso das metas, mais elas experimentam bem-estar na vida em geral e mais florescem no trabalho. A maioria das relações entre metas de carreira, bem-estar e florescimento no trabalho é positiva, o que é consistente com estudos anteriores. Futuros estudos poderiam analisar em quais condições contextuais específicas a busca de metas de carreira teria maior ou menor impacto sobre o bem-estar e o florescimento no trabalho. 


\section{PALAVRAS-CHAVE}

Bem-estar subjetivo. Florescimento no trabalho. Realização profissional. Carreira. Metas.

\section{REFERENCES}

Albuquerque, A. S., \& Tróccoli, B. T. (2004). Desenvolvimento de uma escala de bem-estar subjetivo. Psicologia: Teoria e Pesquisa, 20(2), 153-164. doi:10.1590/S0102-37722004000200008

Andrews, F. M., \& Withey, S. B. (1976). Social indicators of well-being: America's perception of life quality. New York: Plenum Press.

Anguas, A. (1997). El significado del bienestar subjetivo, su valoración en México (Tesis de Maestría en Psicología Social, Universidad Nacional Autónoma de México, Madrid, España).

Baltes, P. B., \& Baltes, M. M. (Eds.). (1990). Successful aging: Perspectives from the behavioral sciences. New York: Cambridge University Press.

Bono, J., Davies, S., \& Rasch, R. (2011). Some traits associated with employee flourishing. In K. Cameron \& G. Spreitzer (Eds.), Handbook of positive psychology. Oxford: Oxford University Press.

Briscoe, J. P., \& Hall, D. T. (2006). Special section on boundaryless and protean careers: Next steps in conceptualizing and measuring boundaryless and protean careers. Journal of Vocational Behavior, 69, 1-3. doi:10.1016/j. jvb.2005.09.005

Brunstein, J. C. (1993). Personal goals and subjective well-being: A longitudinal study. Journal of Personality and Social Psychology, 65, 1061-1070. doi:0.1037/0022-3514.65.5.1061

Brunstein, J. C., Schultheiss, O. C., \& Grässmann, R. (1998). Personal goals and emotional well-being: The moderating role of motive dispositions. Journal of Personality and Social Psychology, 75(2), 494-508. doi:10.1037// 0022-3514.75.2.494

Cantor, N., \& Fleeson, W. (1994). Social intelligence and intelligent goal pursuit: A cognitive slice of motivation. In R. Dienstbier (Series Ed.) \& W. D. Spaulding (Volume Ed.), Nebraska symposium on motivation (Vol. 41, pp. 125-179). Lincoln: University of Nebraska Press. 
Cantor, N., \& Sanderson, C. A. (1999). Life task participation and wellbeing: The importance of taking part in daily life. In D. Kahneman, E. Diener, \& N. Schwarz (Eds.), Well-being: The foundations of hedonic psychology. New York: Russell Sage Foundation.

Carver, C. S. (2004). Self-regulation of action and affect. In R. F. Baumeister \& K. D. Vohs (Eds.), Handbook of self-regulation: Research, theory, and applications (pp. 13-39). New York: Guilford Press.

Carver, C. S., \& Scheier, M. F. (1998). On the self-regulation of behavior. Cambridge: Cambridge University Press.

Csikszentmihalyi, M. (1993). Flow: The evolving self. New York: HarperCollins.

Deci, E. L., \& Ryan, R. M. (2000). The "what" and "why" of goal pursuits: Human needs and the self-determination of behavior. Psychological Inquiry, 11, 227-268. doi:10.1207/S15327965PLI1104_01

Diener, E. (1995). A value based index for measuring national quality of life. Social Indicators Research, 36(2), 107-127. doi:10.1007/BF01079721

Diener, E. (2001). Subjective well-being. In N. J. Smelser \& P. B. Baltes (Eds.), International encyclopedia of the social \& behavioral sciences. Oxford: Elsevier.

Diener, E., \& Fujita, F. (1995). Resources, personal strivings, and subjective well-being: A nomothetic and idiographic approach. Journal of Personality and Social Psychology, 68(5), 926-935. doi:10.1037/0022-3514.68.5.926

Diener, E., Oishi, S., \& Lucas, R. E. (2002). Subjective well-being: The science of happiness and life satisfaction. In C. R. Snyder \& S. J. Lopez (Eds.), Handbook of Positive Psychology. Oxford: Oxford University Press.

Diener, E., Suh, E. M., Lucas, R. E., \& Smith, H. L. (1999). Subjective wellbeing: Three decades of progress. Psychological Bulletin, 125(2), 276-302. doi:10.1037/0033-2909.125.2.276

Diener, E., Wirtz, D., Tov, W., Kim-Prieto, C., Choi, D. W., Oishi, S., \& Biswas-Diener, R. (2010). New well-being measures: Short scales to assess flourishing and positive and negative feelings. Social Indicators Research, 97, 143-156. doi:10.1007/s11205-009-9493-y

Emmons, R. A. (1986). Personal strivings: An approach to personality and subjective well-being. Journal of Personality and Social Psychology, 51(5), 1058-1068. doi:10.1037/0022-3514.51.5.1058

Emmons, R. A. (1989). The personal striving approach to personality. In L. A. Pervin (Ed.), Goal concepts in personality and social psychology (pp. 87-126). Hillsdale, NJ: Erlbaum. 
Emmons, R. A., \& Diener, E. (1986). A goal-affect analysis of everyday situational choices. Journal of Research in Personality, 20(3), 309-326. doi:10.1016/0092-6566(86)90137-6

Emmons, R. A., \& Kaiser, H. (1996). Goal orientation and emotional wellbeing: Linking goals and affect through the self. In A. Tesser \& L. Martin (Eds.), Striving and feeling: Interactions among goals, affect, and self-regulation (pp. 79-98). New York: Plenum Press.

Faul, F., Erdfelder, E., Lang, A. G., \& Buchner, A. (2007). G*Power 3: A flexible statistical power analysis program for the social, behavioral, and biomedical sciences. Behavior Research Methods, 39(2), 175-191. doi:10.37 58/BF03193146

Freund, A. M., \& Baltes, P. B. (2002). Life-management strategies of selection, optimization, and compensation: Measurement by self-report and construct validity. Journal of Personality and Social Psychology, 82 (4), 642-662. doi:10.1037/0022-3514.82.4.642

Gevers, J., Mohammed, S., \& Baytalskaya, N. (2015). The conceptualisation and measurement of pacing styles. Applied Psychology: An International Review, 64(3), 499-540. doi:10.1111/apps.12016

Hall, D. T. (2002). Protean careers in and out of organizations. Thousand Oaks, CA: Sage.

Heckhausen, J. (1999). Developmental regulation in adulthood: Age normative and sociostructural constraints as adaptive challenges. Cambridge, England: Cambridge University Press.

Hortop, E. G., Wrosch, C., \& Gagné, M. (2013). The why and how of goal pursuits: Effects of global autonomous motivation and perceived control on emotional well-being. Motivation and Emotion, 37(4), 675-687. doi:10.1007/s11031-013-93492

Jackson, T., Weiss, K. E., Lundquist, J. J., \& Soderlind, A. (2002). Perceptions of goal-directed activities of optimists and pessimists: A personal projects analysis. The Journal of Psychology, 136(5), 521-532. doi:10.10 80/002239 80209605548

Judge, T. A., Locke, E. A., Durham, C. C., \& Kluger, A. N. (1998). Dispositional effects on job and life satisfaction: The role of core evaluations. Journal of Applied Psychology, 83(1), 17-34. doi:10.1037/0021-9010.83.1.17

Kehr, H. M. (2003). Goal conflicts, attainment of new goals, and well-being among managers. Journal of Occupational Health Psychology, 8(3), 195-208. doi:10.1037/1076-8998.8.3.195 
Keyes, C. L. M., \& Haidt, J. (Eds.). (2003). Flourishing: Positive psychology and the life well lived. Washington: American Psychological Association.

Klug, H. J. P., \& Maier, G. W. (2015). Linking goal progress and subjective well-being: A meta-analysis. Journal of Happiness Studies, 16(1), 37-65. doi:10.1007/s10902-013-9493-0

Kruglanski, A. W. (1996). Motivated social cognition: Principles of the interface. In E. T. Higgins \& A. W. Kruglanski (Eds.), Social psychology: Handbook of basic principles (pp. 493-520). New York: Guilford.

Lucas, R. E., Diener, E., \& Suh, E. (1996). Discriminant validity of wellbeing measures. Journal of Personality and Social Psychology, 71 (3), 616-628. doi:10.1037/0022-3514.71.3.616

Luthans, F. (2002). Positive organizational behavior: Developing and managing psychological strengths. Academy of Management Executive, 16 (1), 57-72. doi:10.5465/AME.2002.6640181

Leung, B. W., Moneta, G. B., \& McBride-Chang, C. (2005). Think positively and feel positively: Optimism and life satisfaction in late life. International Journal of Aging and Human Development, 61 (4), 335-365. doi:10.2190/ FQTB-EBAJ-H9WP-LMYA

Martinez, M. \& Garcia, M. (1994). La autopercepción de la salud y el bienestar psicológico como indicador de calidad de vida percibida en la vejez. Revista de Psicología de la Salud, 6(1), 55-74.

McAdams, D. P. (1995). What do we know when we know a person? Journal of Personality, 63, 365-396.

Mehrotra, S., \& Tripathi, R. (2013). Flourishing at work. In S. Pandey \& D. M. Pestonjee (Eds.), Stress and work: Perspectives on understanding and managing stress (pp. 239-263). New Delhi: Sage Publications India.

Mendonça, H., Caetano, A., Ferreira, M. C., Sousa, I. F., \& Silva, A. J. (2014). Florescimento no trabalho. In M. M. M. Siqueira (Ed.), Novas medidas do comportamento organizacional: Ferramentas de diagnóstico e de gestão (pp. 172-177). Porto Alegre: Artmed.

Monzani, D., Steca, P., Greco, A., D’Addario, M., Pancani, L., \& Cappelletti, E. (2015). Effective pursuit of personal goals: The fostering effect of dispositional optimism on goal commitment and goal progress. Personality and Individual Differences, 82, 203-214. doi:10.1016/j.paid.2015.03.019

North, R. J., Holahan, C. J., Carlson, C. L., \& Pahl, S. A. (2014). From failure to flourishing: The roles of acceptance and goal reengagement. Journal of Adult Development, 21 (4), 239-250. doi:10.1007/s10804-014-9195-9 
Oishi, S., \& Diener, E. (2001). Goals, culture, and subjective well-being. Personality and Social Psychology Bulletin, 27(2), 1674-1682. doi:10.1177/ 01461672012712010

Oishi, S., Diener, E., Suh, E., \& Lucas, R. E. (1999). Values as a moderator in subjective well-being. Journal of Personality, 67, 157-184. doi:10.1111/ 1467-6494.00051

Oliveira-Silva, L. C. (2015). The importance of achieving what you value: A career goal framework of professional fulfilment (Tese de doutorado, Universidade de Brasília, Brasília, DF, Brasil).

Oliveira-Silva, L. C., Porto, J. B., \& Arnold, J. (2019). Professional fulfilment: Concept and instrument proposition. Psico-USF, 24(1), 27-39. doi:10.15 90/1413-82712019240103

Peterson, C., Park, N., \& Seligman, M. E. P. (2006). Greater strengths of character and recovery from illness. Journal of Positive Psychology, 1, 17-26. doi:10.1080/17439760500372739

Scheier, M. F., \& Carver, C. S. (1992). Effects of optimism on psychological and physical well-being: The influence of generalized outcome expectancies. Health Psychology, 16(2), 201-228. doi:10.1007/BF01173489

Schwartz, S. H. (1992). Universals in the content and structure of values: Theoretical advances and empirical tests in 20 countries. In M. P. Zanna (Ed.), Advances in experimental social psychology (pp. 1-65). San Diego, CA: Academic.

Schwartz, S. H., Cieciuch, J., Vecchione, M., Davidov, E., Fischer, R., Beierlein, C., ... Konty, M. (2012). Refining the theory of basic individual values. Journal of Personality and Social Psychology, 103(4), 663-688. doi:10.1037/a0029393

Sheldon, K. M., \& Elliot, A. J. (1999). Goal striving, need satisfaction, and longitudinal well-being: The self-concordance model. Journal of Personality and Social Psychology, 76(3), 546-557. doi:10.1037/0022-3514.76.3.482

Sheldon, K. M., \& Kasser, T. (1998). Pursuing personal goals: Skills enable progress but not all progress is beneficial. Personality and Social Psychology Bulletin, 24(12), 1319-1331. doi:10.1177/01461672982412006

Silva, A. J., \& Caetano, A. (2011). Validation of the flourishing scale and scale of positive and negative experience in Portugal. Social Indicators Research, 110(2), 1-10. doi:10.1007/s11205-011-9938-y

Tabachnick, B. G., \& Fidell, L. S. (2001). Using multivariate statistics. Boston, MA: Allyn \& Bacon. 
Veltman, A. (2015). Is Meaningful work available to all people? Philosophy and Social Criticism, 41 (7), 725-747. doi:10.1177/0191453714556692

Wanberg, C. R., Zhu, J., \& Van Hooft, E. A. J. (2010). The job search grind: Perceived progress, self-reactions, and self-regulation of search effort. Academy of Management Journal, 53(4), 788-807. doi:10.5465/amj.2010. 52814599

Wiese, B. S. (2007). Successful pursuit of personal goals and subjective wellbeing. In B. R. Little, K. Salmela-Aro, \& S. D. Phillips (Eds.), Personal project pursuit: Goals, action and human flourishing (pp. 301-328). Hillsdale, NJ: Lawrence Erlbaum.

Wiese, B. S., \& Freund, A. M. (2005). Goal progress makes one happy, or does it? Longitudinal findings from the work domain. Journal of Occupational and Organizational Psychology, 78, 287-304. doi:10.1348/096317 905X26714

\section{AUTHOR NOTES}

Ligia C. Oliveira-Silva, PhD from the Department of Social and Work Psychology, University of Brasília (UnB); Juliana B. Porto, PhD from the Department of Social and Work Psychology, University of Brasília (UnB).

Ligia C. Oliveira-Silva is now adjunct professor of Organizational and Work Psychology at the Institute of Psychology (IPUFU) of Federal University of Uberlândia (UFU); Juliana B. Porto is now coordinator of the Graduate Program in Social, Work and Organizational Psychology and associate professor at the Institute of Psychology of University of Brasília (UnB).

Correspondence concerning this article should be addressed to Ligia C. Oliveira-Silva, Avenida Maranhão, s/n, Universidade Federal de Uberlândia, campus Umuarama, Uberlândia, Minas Gerais, Brasil, CEP 38405-240.

E-mail: ligiacarol@ufu.br

\section{EDITORIAL BOARD}

Editor-in-chief

Gilberto Perez

Associated editor

Sônia Maria Guedes Gondim

Technical support

Vitória Batista Santos Silva

\section{EDITORIAL PRODUCTION}

Publishing coordination

Jéssica Dametta

Layout designer

Editorial intern

Paula Di Sessa Vavlis

Graphic designer

Language editor

Daniel de Almeida Leão 